Dilemas de la Traducción. Políticas. Poéticas. Críticas

Susana Romano Sued México: Edición del Centro

Peninsular en Humanidades y en

Ciencias Sociales UNAM, 2016.

\section{Ceremonias de la letra}

Silvia N. Barei ${ }^{\bullet}$

Universidad Nacional de Córdoba, Argentina

Con la misma problemática como eje que recorre la producción de Susana Romano Sued, esta obra hilvana nuevas reflexiones para la comprensión de una teoría diferenciada de la traducción y de su relación con el fenómeno literario. En este empeño, Romano se opone acertadamente a un criterio serialista homogeneizante cuyo efecto último provoca el colapso de toda posibilidad de captación del objeto a estudiar. Estos dilemas son la marca de ciertos callejones sin salida en los que suele caer la teoría de la traducción y de algunos aciertos en el nivel de la historia de sus propias reflexiones.

El desarrollo de una lectura comparatista y contrastiva le ha permitido a la autora la incorporación de modelos y autores que discuten dialógicamente, dentro del mismo canon eurocéntrico (Reiner María Rilke y Paul Celan) o aún en un más allá solo posible por la traducción (Theodor Adorno y Jorge Luis Borges, pero también lo global y lo local, la identidad y la otredad). Estas reflexiones muestran que la autoridad procede no de un nombre o una lengua, sino del modo en que los procesos de memoria — muchas veces asimétricos y sometidos al olvido y las diásporas-, incorporan los textos en diferentes tramas de densidad social.

Desmantelado el mito entre la identidad plena entre «original» y traducción, uno percibe que el valor más importante de esta obra de Susana Romano, El dilema de la traducción consiste en su resistencia a las versiones más tradicionales preocupadas por impugnarle a los traductores cada traición y distorsión imaginable de los originales.

Se trata de operar en un lugar crítico que perturbe los cánones de las teorías de la traducción, las retóricas conocidas y los estatutos «aceptables» impuestos por las poéticas clásicas, sin establecer ninguna complicidad orgánica con los valores que claman por una «traducción fiel»o, en otro extremo, por una apropiación vernácula exenta de «impurezas extranjeras».

Situar el problema de la traducción en el ámbito de una reflexión sobre el lenguaje y la subjetividad permite a la autora ubicarse en la situación incómoda del

- Doctora en Letras Modernas. Ha publicado libros en su especialidad - Teoría Literaria y Teoría de la Cultura - entre los que se destacan Reversos de la palabra, Poesía y vida cotidiana y Culturas en conflicto. Ha publicado seis libros de poemas, el último titulado Nosotras. Ha sido Decana de la Facultad de Lenguas y Vicerrectora de la Universidad de Córdoba. 
«polemos» desde donde se sostiene un pensamiento original. «Itinerancia», «viaje», «travesía», «diáspora», "pasaje» son palabras caras a Romano y que utilizadas en muchos de estos textos señalan una deriva incesante entre escritura del ensayo, reflexión y práctica de la traducción y ejercicio constante de la poesía, labor múltiple distinguida por la Secretaría de Cultura de Buenos Aires con una mención de honor por este libro singular.

Si las culturas son plurales y también lo son sus lenguajes y la constitución de sus sujetos, este estudio habla de esa capacidad significativa de un modo de enunciar que abre a otros ámbitos de la lengua y que pone en el centro la palabra viva —su corporeidad, su intersubjetividad, sus conflictos-. Habla también de las redes de la sociedad contemporánea, sobre todo la latinoamericana, que se sostiene en la idea de una permanencia en constante movimiento.

Comparto con Susana nuestra profesión de fe en la palabra, nuestra idea del trabajo literario como «un ensamble de textos y lenguas», nuestro empeño en «olvidar la amenaza de lo imposible y transitar el camino, más aliviado, de lo probable. Un camino, en fin, desde donde se puede resistir». 